\title{
Robert Piotrowski
}

\section{Cybernetyka i literatura}

\author{
Benjamin BüHLER, Lebende Körper. Biologisches und \\ anthropologisches Wissen bei Rilke, Döblin und Jünger, \\ Königshausen \& Neumann, Würzburg 2005, s. 325.
}

Benjamin Bühler, z wykształcenia biolog, filozof i germanista, jest obecnie profesorem w Zentrum für Literatur- und Kulturforschung w Berlinie. Jego zainteresowania są głównie literaturoznawcze, jednak omawiana monografia (której tytuł należy przełożyć następująco: „Żywe ciała. Wiedza biologiczna i antropologiczna u Rilkego, Döblina i Jüngera") ma charakter interdyscyplinarny, co pozwala nam odnieść się do jej aspektu filozoficznego. Oprócz wprowadzenia na temat obrazu poznawczego (Wissensfigur) żywego ciała książka zawiera dziewięć rozdziałów głównych i zakończenie. Omawia się w nich systemy regulacyjne, debatę mechanizmu z witalizmem, pojęcia Gestalt i systemu, Maxa Schelera, Helmutha Plessnera, Arnolda Gehlena, Rilkego, Döblina i Jüngera; zakończenie znowuż dotyczy technik regulacyjnych.

Autorów omówiono więcej niż tylko trzech wymienionych w tytule, o tych pisze się dopiero pod sam koniec. Jak widać, osią książki są związki między ideami zawartymi w dziełach literackich i filozoficznych a cybernetyką, wiedzą o sterowaniu. W książce wielokrotnie używa się niewymiennych z fachowego punktu widzenia terminów „regulacja” i „sterowanie”, przeto należy wyjaśnić, iż w niemczyźnie jeszcze ostrzej niż w polszczyźnie wyróżnia się sensu stricte regulację (Regelung) na tle sterowania w szerokim pojęciu (Steuerung). To pierwsze oznacza taki wpływ jednego systemu na drugi, w którym sterownik uwzględnia odpowiedź sterowanego, mianowicie regulator ,pilnuje” bieżącej war- 
tości regulowanego parametru (Iswert) w układzie regulowanym, „sprawdzając", czy zadana wartość (Sollwert) została osiągnięta i utrzymana. Oznacza to sterowanie w pętli ujemnego sprzężenia zwrotnego. W przypadku sterowania w szerokim pojęciu chodzi tylko o wpływanie przez jeden układ na parametry drugiego bez uwzględniania odpowiednich reakcji. W angielskim oba pojęcia obejmuje $\mathrm{z}$ reguły termin control, w przypadku sterowania uściśla się to przy pomocy terminu „układ otwarty” (open-loop system), a jeśli chodzi o regulację — używa się „układu zamkniętego” (closed-loop system).

Zgodnie z tytułem wprowadzenia punkt wyjścia rozważań stanowi pojęcie obrazu poznawczego żywego ciała. Jest to wyobrażenie, czy też macierz samokonstytuującej, samoreregulującej i samosterującej się całości, dająca się nakładać na maszyny, zwierzęta, ludzi i społeczeństwa. Autor zamierzył przegląd przykładów takich nałożeń. Nie podjął się jednak ogólnej odpowiedzi na zadawane przy okazji pytanie, czy życiu należy przypisać nieredukowalną autonomię, czy też koncepcję organizmów faktycznie da się sprowadzić do kategorii fizykalnych. Rzecz jasna, szczegółowych odniesień do tej ostatniej kwestii i tak nie dało mu się uniknąć.

Jednym z pierwszych pisarzy przywoływanych przez Bühlera jest francuski filozof i lekarz Georges Canguilhem (1904-1995). Z jego dzieł najbardziej znanym jest Essai sur quelques problèmes concernant le normal et le pathologique (La Montagne, Clermont-Ferrand 1943), rozszerzone w roku 1966 pt. Le normal et le pathologique, augmenté de Nouvelles réflexions concernant le normal et le pathologique. ${ }^{1}$ Canguilhem podkreślał aktywność organizmów na tle ich środowisk, nie będąc witalistą poważnie traktował ten kierunek myślowy, stając tym samym w opozycji do darwinizmu. Niestety, popierając karierę kogoś takiego, jak Foucault, filozofii chcąc nie chcąc zaszkodził. Współczesna recepcja Canguilhema została zanieczyszczona bełkotem całej generacji psychoanalityczno-marksistowskich dywersantów (Althussera, Bourdieu i innych).

\footnotetext{
${ }^{1}$ Przekład: Georges CAnguilhem, Normalne i patologiczne, przeł. Paweł Pieniążek, słowo/ obraz terytoria, Gdańsk 1999.
} 
W trakcie referowania konfrontacji teleo-mechanicystów (Bernard, Lotze, Pflüger) z witalistami (Driesch) pojawia się wskazany wyżej problem obiektywnej niezależności żywego organizmu. Jak wiadomo, w dyskusjach o autonomii i wolności ludzkiej występuje między innymi dylemat: uwzględniać tylko, czy ktoś może czy nie wykonać jakąś czynność bez przeszkód (i wtedy mówi się, iż ów jest „wolny”) — lub poszukiwać jeszcze jakiejś wewnętrznej podstawy autonomii. Da się to łatwo uogólnić na szerszą klasę systemów żywych. Teleo-mechanicyści oczywiście reprezentowali pierwsze podejście, a witaliści drugie, domniemając w organizmach nieempirycznej i niematerialnej „entelechii”.

Próby wyjścia poza przeciwstawienie wymienionych stanowisk - podjęto w kierunku idei doświadczalnie weryfikowalnego czynnika scalającego, co uwydatniło się na gruncie idei holistyczno-systemowych, szczególniej doktryny pola biologicznego Aleksandra Gurwicza (obecnie uznawanej za nibynaukę) ${ }^{2}$ i psychologii Gestalt ${ }^{3}$ Köhlera, Koffki i Wertheimera (w szerszym, ponadpsychologicznym kontekście pisze się o Ganzheitlehre, doktrynie holistycznej). Atoli kurtuazyjna forma polemiki Driescha z Köhlerem nie zdołała zatrzeć dzielących ich różnic. ${ }^{4}$ Co do powojennej ogólnej teorii systemów von Bertalanffy'ego Bühler wskazuje na zjawisko drugiej religijności (zweite Religiosität). Termin ów pojawił się jeszcze u Spenglera, gdzie oznaczał sprymitywizowaną, nasyconą przesądami i rozproszkowaną na sekty religijność pojawiającą się u schyłku formacji kulturowej. ${ }^{5}$ Bühlerowi chodzi jednak o sens, który nadał

\footnotetext{
2 Александр Гурвич, Теория биологического поля, Советская наука, Москва 1944.

${ }^{3}$ Oprócz prac oryginalnych polecić można artykuł Harry'ego Helsona z The American Journal of Psychology: „The Psychology of Gestalt”, July 1925, vol. 36, no. 3, s. 342-370; October 1925 , vol. 36 , no. 4, s. 494-526; January 1926, vol. 37, no. 1, s. 25-62; January 1928, vol. 40, no. 1, s. 172.

${ }^{4}$ Hans Driesch, „Kritisches zur Ganzheitslehre”, Annalen der Philosophie und philosophischen Kritik 22 Dezember 1926, Bd. 5, H. 9/10, s. 281-304; Hans Driesch, „«Physische Gestalten» und Organismen", Annalen der Philosophie und philosophischen Kritik 30 Mai 1925, Bd. 5, H. 1, s. 1-11.

${ }^{5}$ Oswald Spengler, Der Untergang des Abendlandes. Umrisse einer Morphologie der Weltgeschichte, Bd. 2, Welthistorische Perspektiven, C.H. Beck, Monachium 1922, s. 382-388.
} 
drugiej religijności kilka lat później von Bertalanffy: mianowicie tradycji neomistycznej idącej od Kuzańczyka, przez Bruna do Bergsona. ${ }^{6}$

Dość dużo miejsca autor poświęca Helmuthowi Plessnerowi, nie tylko jego rekonstrukcji polemiki Driescha z Köhlerem, także idei człowieka jako organizmu cieleśnie zamkniętego (choć systemowo otwartego i nie mającego skończonego horyzontu) $\mathrm{w}$ równowadze chwiejnej, dążącego do homeostazy. ${ }^{7}$ Terminy „samosterowanie” i ,samoregulacja” występują u Plessnera explicite: odpowiednio w trakcie rozważań o procesualności oraz o dynamice rozwojowej organizmów. ${ }^{8}$ Interesujące okazują się komentarze do (para)cybernetycznych wątków u Schelera ${ }^{9}$ (sytuacja człowieka w erze zaniku przeciwieństw, Weltalter des Ausgleichs) oraz Gehlena ${ }^{10}$ (zastosowania pojęcia sprzężenia zwrotnego w antropologii ${ }^{11}$ ). Człowiek jest zwierzęciem jeszcze nieustalonym (das noch nicht festgestellte Tier), ${ }^{12}$ wymagającym stabilizacji instytucjonalnej, analogicznie jak

${ }^{6}$ Ludwig von BertalanfFy, Nikolaus von Kues, Georg Müller, Monachium 1928; przedruk: Religio. Relisiöse Gestalten und Strömungen, Bd. 2., Georg Müller, Monachium 1929 (oddzielna paginacja).

${ }^{7} \mathrm{O}$ zasadzie homeostazy jako założeniu cybernetyki por. nasz artykuł: Robert PIoTRowski, „Filozoficzne założenia cybernetyki”, The Peculiarity of Man 2012, nr 16, pkt. 6 a.

${ }^{8}$ Helmuth Plessner, Die Stufen des Organischen und der Mensch. Einleitung in die philosophische Anthropologie, wyd. 3., Walter de Gruyter, Berlin 1975, s. 142, 160-165.

${ }^{9}$ Max Scheler, „Der Mensch im Zeitalter des Ausgleichs”, w: Henri Lichtenberger et al., Ausgleich als Augabe und Schicksal, Walter Rotschild, Berlin 1929; przedruk: Max Scheler, Gesammelte Werke, Bd. IX, Späte Schriften, Francke, Berno 1976, s. 145-170. Po polsku: Max SCHeler, „Człowiek w epoce zacierania się przeciwieństw”, przeł. Stanisław Czerniak, w: Max Scheler, Pisma z antropologii filozoficznej i teorii wiedzy, PWN, Warszawa 1987, s. 191-237.

${ }^{10}$ Dobrym wyborem jego pism jest: Arnold Gehlen, Der Mensch: seine Natur und seine Stellung in der Welt, Duncker \& Humblot, Berlin 1940 (liczne przedruki). O wiele mniej reprezentatywna jest polska antologia: Arnold GEHLEN, W kręgu antropologii i psychologii spolecznej: studia, przeł. Krystyna Krzemieniowa, Czytelnik, Warszawa 2001; stanowiąca przekład: Arnold GeHLen, Anthropologische und sozialpsychologische Untersuchungen, Rowohlt, Reinbek 1986.

${ }^{11}$ Gehlen, Der Mensch..., wyd. 9., Athäneum Verlag, Frankfurt n/ Menem 1971, rozdz. 29 i 30: „Rückwirkungen: Die Vorstellung” i „Rückwirkungen: Angleichung der inneren und äusseren Welt".

${ }^{12}$ Gehlen, Der Mensch..., s. 10 - fraze „,der Mensch das noch nicht festgestellte Tier ist” wziął od Nietzschego: Jenseits von Gut und Böse, pkt. 62. 
pozostałe animalia potrzebują stabilizacji instynktowno-środowiskowej. ${ }^{13}$ Uwzględnienie wymienionych koncepcji jest zresztą uzasadnione, skoro legły u podstaw dwudziestowiecznej antropologii filozoficznej.

Natomiast omówienie trzech pisarzy wymienionych w tytule zajmuje około 124 stron, zatem nieco ponad jedną trzecią całej książki. Zaczyna się od Rilkego: Bühler zwraca uwagę na jego ósmą Elegię duinejską, zawierającą zestawienie perspektywy zwierzęcej z ludzką. Autor uznaje to za przykład „,wirtualnego samoopisu". U Alfreda Döblina kładzie nacisk na wizję osoby ludzkiej bliską Plessnerowskiej. U Ernsta Jüngera dostrzega funkcjonalistyczną metafizykę. Niestety, w przeciwieństwie do reszty książki, ostatnie rozdziały są w kontekście głównego wątku pracy niecałkiem przekonujące, głównie ze względu na nieobecność dokładnych odpowiedników koncepcji cybernetycznych w materiale literackim: stwierdzane analogie są w większości raczej odległe, przeto efekty ich wyszukiwania bywają naciągane, może z wyjątkiem Jüngera, u którego koncepcja żywego ciała faktycznie uległa zdecydowanej mechanizacji. Dlatego dosłownie rozumiany podtytuł: „wiedza biologiczna i antropologiczna” można uznać w odniesieniu do ostatnich rozdziałów za adekwatny. W ten sposób okazują się ograniczenia zakresu cybernetycznego obrazu poznawczego jako narzędzia badawczego o interdyscyplinarnym charakterze.

$* * * * *$

Benjamin Bühler's Lebende Körper. Biologisches und anthropologisches Wissen bei Rilke, Döblin und Jünger [Living bodies: biological and anthropological knowledge in Rilke, Döblin und Jünger] is a well-informed study of links between literary-philosophical concepts and the cybernetic outlook. Apart from the three writers mentioned in the title the monograph includes mechanicists, vitalists, Gestalt theorists (in particular Köhler), systemists (von Bertalanffy), and philosophers: Gehlen, Plessner, and Scheler. The crucial concept, introduced at the beginning of the book, is Wissensfigur (cognitive figure) of living body, applicable to machines, animal, men and societies. It includes: totality, and self-control (both in open- and closed loops). Bühler reviews how

\footnotetext{
${ }^{13}$ Gehlen, Der Mensch..., rozdz. 9: „,Tier und Umwelt”.
} 
that Wissensfigur functions in particular cases, however without a comprehensive attempt to answer a related question: whether irreducible autonomy be attributed to life at all.

D

Robert Piotrowski 